\title{
A Synthesis of Corporate Social Responsibility Concept, As a Mechanism to Enhanced Organizational Reputation in Nigeria
}

\author{
Nasiru Saidu ${ }^{1}$ \\ ${ }^{1}$ Department of Business Administration, Bauchi State University Gadau, Nigeria \\ Correspondence: Department of Business Administration, Bauchi State University Gadau, Nigeria. Email: \\ Nasirinta@gmail.com. Tel: +234 8035905206
}

Received: January 20, 2018

Accepted: January 23, 2018

Online Published: January 29, 2018

\begin{abstract}
The connection between corporate philanthropy and firm has strong controversial issues. More so, corporate philanthropy is frequently criticized as an agency cost since it may serve narrow an administrative self-interests. As a society additionally concerned with their environment, organizations have started to transform their activities as a response to deal with the public new concerns. The corporate philanthropy is no doubt an important and attractive case to follow since it brings up quite specific and pronounced ethical issues like environmental resolution. The paper examines CRS using personal observations, dealing with some company's managers, employees and environmentalists, and library research with a view to finding out whether CRS principles can bring a positive impact to the organization. Based on this study, was discovered that, Business firms recognize and practice corporate philanthropy designed to address social development obstacles in Nigeria. The paper therefore recommends that, organizations have to develop a diversity of policies for treating this interesting of community wants and desires, the natural environment, with consequent business imperative and esteem on how intensely and well they are coordinating social responsibility move toward into both policy and routine operations.
\end{abstract}

Keywords: Corporate Philanthropy, Corporate Governance, Organizational Reputation, Stake Holders, Nigeria.

\section{Introduction}

It is important to know that, corporate philanthropy generate firm value and strong repetition in the eyes of society. In current years, customers, suppliers, employees, society, governments, and a number of stake-holders have confidence on business to carry out extra activities in corporate social responsibility (CSR) as mechanism to build their reputation. Most of the business has responded to these concerns by devoting some of their resources to CSR. Otherwise some companies' managers have resisted, in opposition that additional investment in CSR is inconsistent with their efforts to maximize profits. It is therefore an attractive and important area of research as conceivably one of the significant and controversial aspects of the fashionable debate surrounding this area. As a society turns to be more worried with the natural surroundings, businesses firms have started to adapt their performance as a response to deal with society's new anxiety. The corporate philanthropy is no doubt an important and attractive case to follow since it brings up quite specific and pronounced ethical issues like environmental resolution.

Therefore organizations have to develop a diversity of policies for treating with this interesting of communal wants and desires, the natural surroundings, as well as consequent business imperative by means of esteem on how intensely and how healthy they are integrate philanthropic approaches keen on both policy and routine operations. Furthermore a firm ignores to overlook the environment issues in which it transacts their business. Consequently, here is a need to scrutinize the influence of CRS on firm's productivity in nigeria in its more grounded structure, the idea of CSR declares so as to partnerships have an compulsion to consider the interest of clientele, shareholders, workers, society, and also the natural "impression" in all parts of their operations.

Organizational reputation resulting from corporate philanthropy may be an insubstantial strategic resource that increases firm value (Bergstrom and Diedrich, 2011) similarly (Fombrun et al. 2010). However, some organization scholars argue that, corporate philanthropy is primarily an agency cost because it wastes organization resources on social welfare that contributes tiny to firm value (Friedman, 1970; Jensen, 2002; Masulis \& Reza, 2015). Corporate 
philanthropy according to this agency theory view may be a response to social pressures to uphold managers' social status in best circles (Galaskiewicz, 1997).

Many scholars argue that corporate governance mechanisms which comprised CEO, board monitoring, compensation, and CEO power plays a crucial roles in balancing the relationship among corporate philanthropy and firm value. Going by organizational theory, corporate governance research views that firms can align CEO incentives with shareholder interests through compensation contracts and monitoring mechanisms (Daily, Dalton and Cannella, 2003). First, a compensation system that rewards long-term firm value may stimulate CEOs to use corporate philanthropy to increase firm values to the society that both managers and shareholders benefit in the future (Conyon, 2006). while one of the board's fundamental obligations is to screen management, outside executives who hold too numerous directorships in different firms may get to be distracted and lose their focus on the central firm (Fich and Shivdasani, 2006). The subsequent monitoring inadequacies may entice managers to utilize corporate philanthropy in a narrow and self-intrigued way, along these lines contributing little to firm value (Cennamo et al., 2009).

\section{Research Problem}

Nigeria is a country blessed with abundant human and material resources that have been managed by government and some local and global organizations, for them to have some advantages of the resources to provide some amount of utility to its customers through providing various products with the purpose of fulfilling its mission or goal. Over $70 \%$ of these resources are managed by some global and local organizations in which they contribute to the decrease of citizenry welfare by pollutant their environment, killing their roads, reducing their electric power, but most of those organizations are not considering the wellbeing of civilization by taking responsibility for the impact of their activities; their main concern is how to make as much money for their stockholders as possible. Whereas organizations supposed to be willingly taking additional steps to improve standard of living for employees \& their families with the local neighborhood \& society in general. Moreover since most nigerians witness the failure of governments in providing some essential need, therefore it is an advantage by the organization to fill some gaps which will help them to enhance their brand image and reputation in which a strong standing in ecological \& social business be able to help business firm to construct trust increase sales \& consumer reliability, above all study shows to facilitate customers cannot only buy a good products he want but want to be acquainted with that what they purchased was produced in a communally \& environmentally accountable means.

\section{Research Methodology}

The methodology used in the preparation of this paper is to study the library with the document content analysis method. Additional information is obtained from various documents and references to the official website of the relevant agencies. The study also uses content analysis method to data obtained from the literature scholar, newspaper and website in question. The information obtained is used to view the corporate social responsibility concept, as a mechanism to enhanced organizational reputation in Nigeria.

This paper also stems from personal observation on how organizations are taking CSR as waste of company resources, more so, their main concern is how get out and sell more product/services to make profit line. After basic examination of the devastating effects of this act, the author considered proffering answer for the problem as a result of which some observation were made with some companies' managers, employees and environmentalists. The author utilizes these as a part of expansion desk research to build up the paper. Effort was made to concoct workable recommendations that can spare the unsafe circumstance.

4. Literature Review

It should be noted from the beginning that corporate social responsibility CRS no universally accepted definition, some see CSR as simply charity by a dissimilar name, while some sees as an efforts organization make beyond its rule of existence to achieve the equilibrium needs of stakeholders with the need to improved their productivity and make a profit. Corporate Social Responsibility is the ongoing commitment by business to perform morally and bestow to economic improvement though improving the standard of living of the labor force and their families as well as of the local neighborhood and society in general. (Holmes, L., and R. Watts 2000).

The notion "Corporate Social philanthropy" has been distinct in variety of ways by different authors on social philanthropy observe the idea as a nature of a business firm to display "Evangelist rather than "Employed contender" state of mind towards the general public. (Holmes and watts 2000:19) Representing Global Business Council for Sustainable improvement give a reasonable envoy description as: The continued dedication by business to perform morally and help to economic growth while improving the standard of living of the workforce, their relatives as well as those of the local neighborhood and society in general. In a influential findings Carroll (1979, p. 500) delivered corporate philanthropy as build that "incorporate the monetary, legitimate, moral, and optional desires that the general public has with organizations at a provider in a known point in time." Based on his description, Carroll contended that these obligations are execute for the business firm's purpose as well as for society in general. This 

commits the partnership to take the wellbeing of society keen on thought when deciding (Andreasen and Drumright, 2001).

The build CSR has four closely connected aspects - monetary, legitimate, moral standard and charitable -which business firms endeavoring to accomplish every one of the four at all circumstances. In view of these parts, a socially capable firm have to endeavor to create a advantage, obey with the law, be ethical, and be a polite corporate citizen'" (Carroll, 1991, p. 43).' "The social philanthropic firms incorporates the ethical, discretionary expectations that the environment needs an organization at a given in period of time". Caroll (1979:98). 17

- Legal, the Legal responsibility means that the business firm has to its society to comply with the rules and regulation that "engage in recreation by the rules of the game". (Lantos 2001:6).

- Ethical responsibility grasps the scope of principles, models with desires that reproduce a anxiety for what customers, workers, share-holders and the group of people observe as fair, now or in custody with respect for or defense of stakeholders moral human rights. Caroll, (1997:100).

- Economic, A business firms financially duty to the overall population involves creating products and ventures that society needs and setting them at a reasonable value that society needs and acknowledges. The products and enterprises must meet of value standard.

- Discretionary responsibilities are absolutely intentional and frequently guided by the individual estimations of a person inside an organization. They go past the legitimate and are not for the most part expected in moral sense. Caroll's description remains a helpful reason for investigation as it consolidates the basic parts of an association's duty to society.

Conceptualization of CSR (see Carroll, 1999 for a study) ranges from a wide point of view of CSR "as exercises that appear to further some social great, past the interests of the firm furthermore, that which is required by law" (McWilliams and Siegel, 2001, p. 117) to one that is scarcely connected with on boosting shareholder wealth (Goodpaster, 1991)

These ascertained assortments reflect distinctive degrees of obligation credited to a firm past its part as an economic establishment (Hemphill, 1997). In this review, the more broad societal perspective is gotten, portraying CSR as the association's "status and activities" as for its responsiveness to its obvious societal duties (Brown and Dacin, 1997, p. 68 ) as they apply to all association accomplices. Under this definition, an association is resolved to make a move to "guarantee and improve both the welfare of the overall population all things considered and the energy of a business" (Davis and Blomstrom, 1975, p. 6).

As express by (Andrews 1977:43), the idea of corporate social responsibility can be explained as the intellectual and objective anxiety that oblige people regardless of how profitable, and leads them toward the constructive commitment to human advancement. Luttons and Hodget (1976: 24) distinguished it as the way to follow those strategies, to implement judgment, or to follow these lines of actions which are alluring as far as goal and estimation of the general public.

The significance role of CSR goes beyond a company's simple charitable work. In some study, more than $69 \%$ of managerial personnel believed that CSR practices could be a competitive strategy for their business (Barber\& Venkatachlam, 2013), This aspect goes ahead of the simple social activity like educating people regarding a cause or promoting a social campaign (Eagle et al., 2013). therefore, it to be sure dovetails the tourism firms' CSR practice with social marketing subsequent to impacting individuals conduct is the center primary concern of social marketing (Andreasen, 1994). Also, it parallels Kotler and Roberto's (1989, p. 6) argues that social marketing is "a prearranged effort carryout by one group (the agent of change), which expects to induce other to acknowledge, modify, or desert certain thoughts, attitudes, practices, and behaviors.' As the definition of CSR explains, one area of CSR is to improve the quality of group, individuals and society wellbeing. in a different way affirmed that regardless of the way that organizations may accomplish their own marketing benefits through CSR association, it goes with the fundamental component of social marketing that its essential center is on doing good and advancing social benefits (Rangun and Karim, 1991). As a standout amongst the most widely recognized area for social marketing effort (Kotler et al., 2012), sightseeing businesses also put a major emphasis on pro environmental efforts because the environment is a vital component in attracting consumers (Knowles, Macmillan, Palmer, Grabowski, \& Hashimoto, 1999). Strategy researchers, conversely, contend that corporate philanthropy may positively add to firm esteem since it permits firms to accumulate resources that are hard to obtain or develop (Barnett, 2007; Godfrey, 2005). This strategic perspective proposes that firm esteem is made when corporate philanthropy results in an asset blessing that is important, uncommon, and costly to-imitate for competitors (Barney, 1991; Dierickx and Cool, 1989). From this strategic perspective, corporate philanthropy may pick up firm value when it Supports organizational goals (Smith, 1994) or increase the firm's competitive context (Porter \& Kramer, 2002). This may be the case when philanthropic investments create intangible resources (Surroca et al., 2010), such as Firm reputation 
(Fombrun \& Shanley, 1990), trust with customers (Lev et al., S U and Sauerwald 52010), employee satisfaction (Edmans, 2012), and positive stakeholder relationships (Su \& Tsang, 2015; Wang \& Qian, 2011).

Stakeholder Theory and CSR

A convincing contention behind why business is roused to devote in CSR activities originates from the area of stakeholder theory (Argandona, 1998; Freeman, 1984; Harvey and Schaefer, 2001; Post, 2003). Stakeholder theory proposes so as to hierarchical continued existence with achievement be dependent upon on fulfilling equally its economic (e.g. profit maximization) and non-financial (e.g. corporate social execution) targets via addressing the requirements of the organization's different stakeholders. Previous findings in the field of stake holder administration express the stake holder in a business firm as any group of peoples who can influence or is influenced by the accomplishment of the organizations (Freeman, 1984, p. 46). principal stakeholder groups comprise of customers, suppliers employees, plus shareholders and investor, community entities for example, government or other open associations so as to set laws plus manage financial business and rule economic business (Clarkson, 1995), and exchange affiliations and ecological groups (Donaldson and Preston,1995).

In outline, stakeholder theory proposes so as to organizations are spurred toward expand their goals to incorporate different objectives notwithstanding benefit profit maximization. In view of this theory, much company's grasp a Corporate Social Responsibility agenda as a way to advance socially competent behavior also approaches, furthermore, sufficiently act in response to partner needs (Maignan and Farrell, 2004). Incentive for satisfying stake holders requirements drives from the way that treatment to partner needs can be corresponded through an organization continued existence, monetary affluence, upper than economic well-being, competitive benefit, and the advancement of trust also reliability among its focused on clients (Mitchell et al., 1997).

Corporate Social Responsibility Development in Nigeria

Nigerian government have furthermore through its NEEDS policy (Nigerian National Planning Commission 2004) place the setting by characterizing the personal division business position as by expressing so as to "the personal division are required toward storm up and additional practical in creating dependable jobs, increasing their profitability, more, improving the standard of living quality to its citizenry . More so anticipated that increased socially competent by allocating resources into corporate social responsibility and communal improvement of Nigeria.

Furthermore an international compress network was legitimately launched in Nigeria during the 12th Annual Nigerian Economic Summit in Abuja in 2006 where some Nigerian organizations have effectively signed on to the international Compact. Moreover an international compress system was formally established in Nigeria through $12^{\text {th }}$ yearly Nigeria economic meeting in Abuja 2006 in which a number of Nigerian business.

Where by Nigerian oil division ruled by international organizations. To recompense for the government's supremacy failure to ensure self particular business intrigues, the organizations frequently participate in social philanthropy. The historical backdrop of formal corporate social responsibility in Nigeria can be followed rear to the CRS practices in the oil and gas multinational by means of the concentrated on helping the impacts of their withdrawal exercises on the local communities. The organizations gives healing facilities schools, and funnel borne waters, Commonly these activities are specially appointed and not generally supported (Amaeshi, Adi, Ogbechie \& Amao, 2006).

5. Findings

In the process of the research, the synthesis of corporate social responsibility concept, as a mechanism to enhanced organizational reputation in Nigeria, the following are the findings arrived:

- Failure by organizations to engaged in Corporate Social Responsibility has certainly plays a vital role to enlarge incidence and consequences of disagreement among business firms and their host community and consequently on their performance and productivity.

- Most of the organizations are taking corporate social responsibility as an agency cost only few of them take CRS as an obligation to its host community.

- Most of the business management's failed to watch major principle of Corporate Social Responsibility do have influences on the incidence and occurrence of injure and other unfavorable courses on its host neighborhood.

- That effectual monitoring and assessment via all stakeholders of industry communities helps significantly to decrease the occurrence of the company dealing Corporate Social Responsibility with lightheartedness.

- Finally the finding also indicates that investment in Corporate Social Responsibility helps companies to Increase ability to attract \& retain employees. 


\section{Recommendations}

- The first findings express that Failure by organizations to engaged in Corporate Social Responsibility has certainly provide a vital position to enlarge incidence and consequences of disagreement between business firms and their host communities and consequently on their performance and productivity. The rationale behind the idea business organization only concern its profit maximization for its share holders be supposed to be erase and turn into out of date and thus be supposed to forecast on the prominence to a newer word "corporate philanthropy. More over companies should willingly take additional ladder to get better the excellence of life for workers \& their families as well as the local neighborhood \& civilization at large trough providing benefits for employees \& improve the quality of life in the workplace beyond economic \& legal requirements.

- Consider the second findings Most of the organizations are taking corporate social responsibility as an agency cost only few of them take CRS as an obligation to its host community. Nigerian organizations should continuously carry out corporate social responsibility projects and they should carry it out adequately and appropriately in order to ensure sustainability, profitability and a high increase in efficiency, thus, they will absolutely help the organization to increase their sales and customer loyalty. Previous findings shows that customers will not want high-quality and safe products alone additionally needs to know what he buy was produced in a socially and environmentally accountable way. Furthermore its commitment to Corporate Social Responsibility will help in achieving its predetermined goals and objectives.

- Most of the business management's failed to monitor key a standard of Corporate Social Responsibility does contain influences on the incidence and occurrence of injure and other unfavorable courses on its host neighborhood.

The government should collaborator with these organizations to ensure that organization management observes key principles of Corporate Social Responsibility in order to guarantee efficiency in organization its social responsibility activities. With no endanger corporate survival; businessmen should understand the advantages of charitable grants to college's hospitals institutions and to its host group of people, to talk about a few. Business organizations ought to understand so as to an expansion in the entrepreneur strength of the population can merely be advantageous to the business division and that the legislature cannot do this all by you.

- That effectual monitoring and assessment by all stakeholders of business communities helps significantly to decrease the occurrence of the company dealing with Corporate Social Responsibility with levity. The host community leaders/heads or elders pioneers and shareholders ought to insure timely and efficient monitoring or supervision the activities of the companies in their community through this monitoring will help them become more acquainted with the concept of Corporate Social Responsibility. And also seminar and frequent meetings observed by all stakeholders with the aid of the Government and legislations on corporate social responsibility This would keep the diversification of funds by the organization for unapproved purposes like illegal business practices.

- Lastly the finding reveals that investment in Corporate Social Responsibility helps companies to Increase ability to attract \& retain employees. Therefore the Nigerians organizations should continuously consider the interest of their host communities by making impact to their activities that will increase their standard of living, through that will help the organization to Keeping up with competitors and anywhere the marketplace is, and also to attract and retain a productive employees.

\section{Conclusion}

This study demonstrate that corporate social responsibility has accepted as new significant and relevance to an organization productivity and competitive advantages. In the process of the study various literature have been review and shows a number of win-win outcomes and number of organizations are perceived that their CSR opens door for enhancing their opportunity to improved their productivity, reduce operating cost/ increase operational efficiency, enhance brand image \& reputation, Increase sales and customer loyalty, Potentially reduce regulatory oversight, Increase ability to attract \& retain employees and also Keeping up with competitors \& where the market is etc. The study additionally demonstrated that the way to achievement in by means of any type of modernization to a company's benefit from the CSR point of view is to correspondence by means of local community establishment, the push and most outstandingly, the universal public that stands to achieved from such initiative. It is well and appropriate that additional organizations are taking part in CSR connected Activities nowadays, obviously, yet persons that promote the reality are receiving the rewards as far as enhanced their productivity too.

\section{References}

Andreasen, A. and M. Drum wright: 2001,_Alliances and Ethics in Social Marketing_, in A. Andreasen (ed.In Ethical Issues in Social Marketing (Georgetown University Press, Washington, DC). 
www.cribfb.com/journal/index.php/asflbr

Asian Finance \& Banking Review

Vol. 2, No. 1; 2018

Andreasen, A. R. (1994). Social marketing: Its definition and domain. Journal of Public Policy \& Marketing, $13,108-114$.

Amaeshi, K, Adi, B, Ogbechie, C \& Amao, O. (2006) "Corporate Social Responsibility in Nigeria: Western Mimicry or Indigenous Influences?”. No. 39-2006, ICCSR Research Paper Series ISSN $1479-5124$, The University of Nottingham, pp. 4,17, 25.

Argandona, A.: 1998, _The Stakeholder Theory and the Common Good_, Journal of Business Ethics 17(9/10), $1093-1102$.

Barney, J. (1991). Firm resources and sustained competitive advantage. Journal of Management, 17, 99-120.

Barnett, M. (2007). Stakeholder influence capacity and the variability of financial returns to responsibility. Academy of Management Review, 32,794-816.

Barber, N. A., \& Venkatachalam, V. (2013). Integrating social responsibility into business school undergraduate education: A student perspective. American Journal of Business Education (AJBE), 6, 385-396.

Brown, T. J. and P. A. Dacin: 1997,_The Company and the Product: Corporate Associations and Consumer Product Responses_, Journal of Marketing 61(1), 68-84.

Cennamo, C., Berrone, P., \& Gomez-Mejia, L. R. (2009). Does stakeholder management have a dark side? Journal of Business Ethics, 89, 491-507.

Conyon, M. J. (2006). Executive compensation and incentives. Academy of Management Perspectives, 20, 25-44.

Carroll, A. (1991) "The Pyramid of Corporate Social Responsibility: Toward the Moral Management of Organizational Stakeholders". Business Horizons, July-August 1991.

Carroll, A. B.: 1979,_A Three-Dimensional Conceptual Model of Corporate Social Performance_, Academy of Management Review 4(4), 497-505.

Carroll, A. B. (1999). Corporate social responsibility evolution of a definitional construct. Society, 38,268-295.

Clarkson, M. E.: 1995,_A Stakeholder Framework for Analyzing and Evaluating Corporate Performance Academy of Management Review 20(1), 92-118.

Donaldson, T. and L. E. Preston: 1995,_The Stakeholder Theory of the Corporation: Concepts, Implications_, Academy of Management Review 20, 64-91.

Daily, C. M., Dalton, D. R., \& Cannella, A. A. (2003). Corporate governance: Decades of data. Academy of Management Review, 28, 371-382.

Davis, K. and R. L. Blomstrom: 1975, Business and Society: Environment and Responsibility NewYork).

Dierickx, I., \& Cool, K. (1989). Asset stock accumulation and the sustainability of competitive Reply. Management Science, 35, 1514.

Eagle, L., Dahl, S., Hill, S., Bird, S., Spotswood, F., \& Tapp, A. (2013). Social marketing. England: Pearson Education.

Edmans, A. (2012). The link between employee satisfaction and firm value, with implications for responsibility. Academy of Management Perspectives, 26, 1-19.

Fich, E. M., \& Shivdasani, A. (2006). Are busy boards effective monitors? Journal of Finance,

Fombrun, C., Gardberg, N. A., \& Barnett, M. L. (2000). Opportunity platforms and safety nets: citizenship and reputational risk. Business and Society Review, 105, 85-106.

Fombrun, C., \& Shanley, M. (1990). What's in a name? Reputation building and corporate strategy. Academy of Management Journal, 33, 233-258.

Friedman, M. (1970, September 13). The social responsibility of business is to increase its York Times Magazine, pp. 122-126.

Freeman, R. E.: 1984, Strategic Management: A Stakeholder Approach (Pitman Publishing Inc, MA).

Godfrey, P. C. (2005). The relationship between corporate philanthropy and shareholder wealth: management perspective. Academy of Management Review,30, 777-798.

Goodpaster, K. E.: 1991,_Business Ethics and Stakeholder Analysis_, Business Ethics Quarterly

Galaskiewicz, J. (1997). An urban grants economy revisited: Corporate charitable contributions Cities, 1979-81, 1987-89. Administrative Science Quarterly, 42, 445-471.

Hemphill, T. A.: 1997, _Legislating Corporate Social Responsibility_, Business Horizons 40(2),

Harvey, B. and A. Schaefer: 2001,_Managing Relationships with Environmental Stakeholders: Water and Electricity Utilities_, Journal of Business Ethics 30(3), 243-

Holmes, L., and R. Watts (2000) Corporate Social Responsibility: Making Good Business Sense

Business \&

Social

Evidence, and

dialogue and

(McGraw-Hill,

advantage:

London,

corporate social

61, 689-724.

Corporate

profits. New

Marshfield,

A

risk

1(1), 53-74.

in the Twin

53-59.

A Study of U.K. 
(Geneva:World Business Council for Sustainable Development).

Jensen, M. C. (2002). Value maximization, stakeholder theory, and the corporate objective function. Business Ethics Quarterly, 12, 235-256.

Knowles, T., Macmillan, S., Palmer, J., Grabowski, P., \& Hashimoto, A. (1999). The development of environmental initiatives in tourism: responses from the London hotel sector. The International Journal of Tourism Research, 1, 255.

Kotler, P., \& Lee, N. (2004). Corporate social responsibility: Doing the most good for your company and your cause. Hoboken, NJ: John Wiley.

Kotler, P., \& Roberto, E. L. (1989). Social marketing: Strategies for changing public behavior. New Nork, NY:Free Press.

Kotler, P., Hessekiel, D., \& Lee, N. (2012). Good works!: Marketing and corporate initiatives $\quad$ that build a better world ... and the bottom line. Hoboken, NJ: John Wiley.

Lantos, G. P. (2001). The Boundaries of Strategic Corporate Social Responsibility. Journal of Consumer Marketing. Vol. 18(7), Pg. 595-630.

Lev, B., Petrovits, C., \& Radhakrishnan, S. (2011). Making the business case for corporate philanthropy. Director Notes, 3, 1-8.

Maignan, I. and O. C. Farrell: 2004,_Corporate Social Responsibility and Marketing: An Integrative Framework_, Journal of the Academy of Marketing Science 32(1),3-19.

Masulis, R. W., \& Reza, S. W. (2015). Agency problems of corporate philanthropy. Review of Financial Studies, 28, 592-636.

Mitchell, R. K., B.R. Agle and D. J.Wood: 1997,_Toward a Theory of Stakeholder Identification and Salience: Defining the Principle of Who and What Really Counts_, Academy of Management Review 22(4), 853-887.

McWilliams, A. and D. Siegel: 2001,_Corporate Social Responsibility: A Theory of the Firm Perspective_, Academy of Management Review 26, 117-127.

Porter, M. E., \& Kramer, M. R. (2002). The competitive advantage of corporate philanthropy. Harvard Business Review, 80, 56-69.

Post, F. R.: 2003,_A Response to "the Social Responsibility of Corporate Management: A Classical Critique'"Mid-American Journal of Business 18(1), 25-35.

Rangun, V. K., \& Karim, S. (1991). Teaching note: Focusing the concept of social marketing. Boston, MA: Harvard Business School Press.

Surroca, J., Tribó, J. A., \& Waddock, S. (2010). Corporate responsibility and financial performance: The role of intangible resources. Strategic Management Journal, $31,463-490$.

Smith, C. (1994). The new corporate philanthropy. Harvard Business Review, 72, 105-116.

Surroca, J., Tribó, J. A., \& Waddock, S. (2010). Corporate responsibility and financial performance: The role of intangible resources. Strategic Management Journal, 31, 463-

Su, W., \& Tsang, E. W. K. (2015). Product diversification and financial performance: The

490. of secondary stakeholders. Academy of Management Journal, 58, 1128-1148.

Sethi S. Prakash (1979), “A Conceptual Framework for Environmental Analysis of Social Issues and Evaluation of Business Response Patterns", Academy of Management Review, Vol. $4 \quad$ (1), pp. 63-74.

Wang, H., \& Qian, C. (2011). Corporate philanthropy and corporate financial performance: The roles of stakeholder response and political access. Academy of Management Journal, 54, 1159-1181.

\section{Copyrights}

Copyright for this article is retained by the author(s), with first publication rights granted to the journal.

This is an open-access article distributed under the terms and conditions of the Creative Commons Attribution license (http://creativecommons.org/licenses/by/4.0/) 